\title{
日本応用動物昆虫学会第6回シンポジウム記録
}

\author{
（昭和37年 4 月 3 日，虎ノ門共済会館講堂）
}

\section{I 作物の耐虫性}

総論

福田仁郎

（農林省園芸試験場）

作物の耐虫性とは害虫の加害に対する作物の感受性の 程度が低いことを意味し，これを制御しあるいはこれに 関与する因子はすこぶる多い。

いったい作物自体が害虫に対して抵抗を示すときはそ の有する機械的因子または化学的因子, あるいは上記両 者によるものであるがこれらの因子には強度の耐虫性を あらわすものから低位のものに至るまで各種の段階があ り概して前者による事例は少ない。また作物はそれをと りまく環境あるいはそれが作り出寸環境において上記各 因子による一時的あるいはかなり長期にわたる耐虫性を あらわすものである。すなわちたとえば前者の場合土壤 の物理化学的性質によって作物が影響をうけ, その体内 に耐虫性が造成され，また施肥量によっては害虫に対す る感受性が増大あるいは減少する。しかしたとえばリン ゴの Nothernepy（君が袖）は綿虫に対して英国では非 感受性, ドイッでは感受性, Jonathan（紅玉）は日本 では感受性, 英国では非感受性という上うな現象はそれ ぞれ異なった環境下に生育した作物の反応に基づくもの と思われるが綿虫の strain による感受性の相異による とも考穴られる。更に作物の耐虫性は栽培様式やその生 育の過程に执いてそれぞれ異なった因子によってあらわ されるものである。

耐虫性品種の選抜は主として交雑育種法が用いられ， その他突然变異などの利用が行なわれている。これにつ いては今後放射線などの応用が考兄られる。このように して選抜されたものがたと文強度の耐虫性を有しなくと もこれによって薬㓮散布回数の減少を図りらるならば省 力的害蚛除の一環としてとりあげるべきであろう。し かし選抜品種恃市場性があり他の病害虫に対する感受性 が小さくかつ栽培の地域性が大きいことが必要である。
イネカラバエに対する水稲の抵抗性

湯沜健

（農林省農業技術研究所）

イネ品種のイネカラバエに対する抵抗性は古くから知 られており, また, 湯浅, 湖山, 岡本らの諸先彗の研究 がある。しかし，その多くは場における観察に基づい たものである。そこで, 演者および富沢は幼虫をイれに 人工的に接種する実験から得られた結果を中心として述 べたい。イネカラバエには 2 化地帯, 3 化地带の別があ り更にそれぞれの地方によっていくつかの系統に分けら れることが岩田らによって報告されている。演者の行な った実験はすべて埼玉県鴻巣市の 3 化性のものを用いた が, 得られた一般的な知見は, 2 化性, 3 化性の地带に おいても原理的なものについては全く同じであると考兄 ている。

作物の害虫に対する要因としては, 寄主の選好性 (Preference), 生育阻害性(Antibiosis), 而性(Torelance) に集約されることが PAINTER によって提唱されている。 しかし、イネカラバエにおいて産卵の選好性はムラサキ イネなどの特殊な品種を除いてはあまり差異がないこと

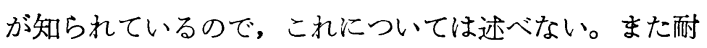
性の因子としてはいくつかの要因が知られているけれど もここでは出穂期の早晚と被害の多少の関係についての み述べるに止める。

\section{幼虫の死亡過程}

ふ化幼虫の食入の難易 : 第 1 表に示されるように, 品 種による食入率の差異は見られない。

第 1 表 抵抗性の違う品種間の食入率の比較 （湯鴄・富沢；未発表）

\begin{tabular}{|c|c|c|c|c|}
\hline $\begin{array}{l}\text { 抵抗性 } \\
\text { の度合 }\end{array}$ & 品 種 名 & $\begin{array}{l}\text { 接 種 } \\
\text { 個体数 }\end{array}$ & $\begin{array}{l}\text { 食 } \text { 合 } \\
\text { 数 }\end{array}$ & $\begin{array}{l}\text { 食入率 } \\
(\%)\end{array}$ \\
\hline 抵抗性 & $\begin{array}{l}\text { 奥羽 } 68 \text { 号 } \\
\text { 酒井金李 }\end{array}$ & $\begin{array}{l}30 \\
30\end{array}$ & $\begin{array}{l}27 \\
29\end{array}$ & $\begin{array}{l}90.0 \\
96.7\end{array}$ \\
\hline 中間性 & $\begin{array}{l}\text { 陸羽 } 132 \text { 号 } \\
\text { 信交 } 190 \text { 号 }\end{array}$ & $\begin{array}{l}30 \\
30\end{array}$ & $\begin{array}{l}29 \\
24\end{array}$ & $\begin{array}{l}96.7 \\
80.0\end{array}$ \\
\hline 感受性 & $\begin{array}{l}\text { 奥羽 } 227 \text { 号 } \\
\text { 竜祖 }\end{array}$ & $\begin{array}{l}30 \\
30\end{array}$ & $\begin{array}{l}28 \\
28\end{array}$ & $\begin{array}{l}91.1 \\
91.1\end{array}$ \\
\hline
\end{tabular}

